\title{
Shaping the future: Professional forestry challenges for the next 50 years ${ }^{1}$
}

\author{
by Larry Pedersen ${ }^{2}$
}

It's my questionable pleasure to try to give you a Forest Service perspective on the professional forestry challenges we can expect in the next fifty years, as we try to shape as much of the future as we can. I say "questionable" because from recent experience one of our biggest challenges is going to be believing the crystal ball we look in today will still show something recognizably similar in a week's time - let alone in fifty years. Really important parts of the broad policy environment are changing at such a rate I may yet have to accept amendments to this address before I've finished giving it to you. So if I break off suddenly and get out my pen... or if my cell phone rings... just try to use a few moments for professional development... or make your own cell phone call... and I'll get back to you as soon as I can.

Over the last fifty years the population of British Columbia roughly quadrupled, our primary harvested species went from Douglas-fir on the coast to lodgepole pine in the interior, and our total harvested volume increased by a factor of about five.

So what will happen in the next half century? Some ill-informed speculators would have us think that if recent trends continue, in fifty years' time there'll be three old-growth trees left in the province that aren't in a park, and they will be patrolled by the Forest Service's one remaining staff person, pushing an old green Suburban, whose wheels and engine had to be sold off to help bail out the last remaining licensee in the province. This staff person would be towing a five-ton trailerload of plans for how to partially cut those last three trees... without touching the ground... while providing habitat for the full range of identified wildlife... and creating several thousand jobs for master guitar makers... and paying enough stumpage to reduce the provincial debt and keep fifty lawyers in Washington for ayear, to convince the US that our one remaining licensee isn't making too much money.

Luckily for us and our successors, that scenario is not a probable outcome, and avoiding it doesn't present much of a challenge. But I'm allowed to present three challenges today, so for the other two I'll try to be a bit more realistic - which shouldn't be hard. It shouldn't be hard because, if there's one profession that promises to be completely fraught with real, difficult, hard-to-deal-with challenges for the foreseeable future, it's our own discipline of forestry.

The heightened interest in forestry in recent years has already made us face up to a lot of important challenges, and woken us up to new ones as well, many of which you've heard about ove the last two days. To my mind it's clear that as we progress through the next fifty years, these and a whole range of other challenges we've begun to recognise will intensify and require our daily attention.

I have to admit I had difficulty deciding which of the many challenges facing our profession today I should speak on.

1Presentation to the 50th Annual General Meeting of the Association of British Columbia Professional Foresters, March 6, 1998, Victoria, BC.

${ }^{2}$ Chief Forester, British Columbia Ministry of Forests, P.O. Box 9525, Stn Prov Govt, Victoria, BC V8W 9C3.
With our talents and capabilities there are many things we can and will be doing in the future to help the province responsibly develop its forest resources. We have challenges such as optimizing the outputs from the forest, ranging from producing revenues and supporting the economy, through to maintaining the rich biological diversity of our forests

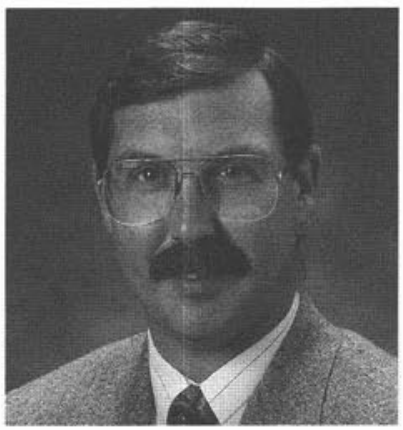
and maintaining basic forest productivity. I could talk all day about timber supply, strategic planning, site productivity, or silvicultural systems and so on. However, I have decided to put some of these - my favourite issues - aside, in favour of focussing on a couple of our newer challenges, both of which are connected in one way or another to all of these topics.

These two challenges are sustainability and accountability. Broadly speaking, the challenge of sustainability is first in defining, and then in achieving, the essential elements of sustainable forest management. And for the foreseeable future, this includes identifying, measuring and basing our management on a full set of rational, agreed-upon criteria and indicators of sustainability. BC and Canada have done a lot of work on this already, but we still have a long way to go and the path is highly complicated by the changing global forestry context.

Equally broadly, the challenge of accountability is to make sure that it's the right people, with the right qualifications and mandates, and facing appropriate consequences in the case of error, who are entrusted to define, implement, monitor and enforce sustainable forest management - and that's the people in this room! I'll say more on that in just a minute.

First I'll deal with sustainability since it's the one overriding policy element we can now count on to be requisite in all we do, although when each of us uses the word it's likely that few of us yet mean exactly the same thing - which is a big challeng in itself. For my purposes today, I want to clarify that I'm using the term sustainability not in the specific sense of characterizing forecasts of timber supplies in relation to longterm harvest levels, but in terms of meeting the broad range of society's desired outcomes from the management of its forests for an optimal mix of short, medium and long-term benefits.

Sustainability - measured by whatever common criteria we can agree on - is now required, and it will continue to be required, environmentally, economically and socially in all aspects of forest management, for two clear reasons. The first is self evident when we consider the long, complex process of evolution that has given us our opportunity to appreciate the current array of biologically diverse life forms that make up our forests. It's natural for us to want to pass on the same opportunity, reasonably intact, to future generations. It's for these reasons that the principles of sustainability have been embedded in the preamble to the Forest Practices Code and are now required in law. The second - and possibly more fiscally persuasive - reason is 
that if we don't manage our forests in ways that our customers recognize as good forest management, we risk losing some of those customers.

There are two challenges facing us in sustainable management. One is in actually managing sustainably, which is what I think we strive to do all the time, and the other is in helping people to understand how and why what we do is sustainable. And there's where I think we have a lot of work to do. The potential loss of market share is now a disturbing issue of increasing immediacy for a growing number of exporters of forest products from BC and also for government. I won't give a lot of detail, since most of you are already familiar with the "green" pressures in the international marketplace - some of which are legitimate, and some less so.

In most ways, $\mathrm{BC}$ is a world leader in the management of lands and resources. Nevertheless, some BC suppliers have already lost contracts with international companies whose customers believe - for whatever reason - that forests in British Columbia are not as well managed as those in some other jurisdictions.

In the short term, these market pressures are likely to become more difficult, rather than easier, to deal with. In Europe last fall I met with successful, well-organized, influential non-government organizations whose members sincerely believe in the need for, and are actively working to bring about, a complete cessation of harvesting in BC's old-growth forests. This may well extend beyond referring only to coastal forests. Some of these organizations also want a complete end to clearcutting. They believe they'll make all this happen within twenty years or sooner, through consumer pressure. They have persuaded customers in the UK and the USA to set up buyers' groups committed to buying only products certified as coming from well-managed forests, and they're already in discussions with Japanese buyers. And guess who does the certifying? They dø! So how seriously should we take all this? The organizations involved have support and they mean business. It's easy for us to want to minimize the likelihood of their success, because that's the most comfortable response for the short-term, and because we believe a rational marketplace will always provide a suitable niche for a good product from well-managed forests such as ours in BC. But the world isn't always rational - or different values create different definitions of what is rational - and unfortunately, pressures generated by interest groups or consumers don't have to suit our sense of what is rational to become serious and expensive.

Just how serious these latest threats to our markets will become is uncertain. But as I speak, government and industry are involved in efforts to assure concerned customers in Europe that British Columbia is a responsible steward of forest lands and resources. We hope that careful efforts and communication will secure our success - because the evidence at the end of the day is on the ground here in $\mathrm{BC}$ in our well managed forests.

There are many competing certification systems under development, such as the Forest Stewardship Council system, ISO 14000, the Candian Standards Association system, and national systems created in Europe. Certification may eventually provide clear direction. But at the moment it's evolving in a very fractious climate. The playing field needs a lot of levelling, and whether we like it or not, we're a long way from the point where the rest of the world takes our word for it that we as professionals know what's best for our forest ecosystems.
Members of a buyers' group in the United Kingdom are saying they'll only buy products from well managed forests certified by a third party auditor and right now for them that means ideally, products certified by the Forest Stewardship Council. The FSC has to date produced no regional standards against which forest management in British Columbia can be evaluated. Some of the principles, however, are currently written in ways that would suggest that FSC certification may not extend to those who harvest in primary forests or in jurisdictions where Aboriginal land claims remain unresolved.

Fortunately, the requirement on primary forests is under review, and you have heard Mr. John on the issue of land claims. From the latest signals, it's my best guess that the FSC will eventually be able to approve some harvesting in original forests. But from the European market perspective, the acceptability of varying levels of disturbance in old-growth or original forests is not yet clear, and we can't assume our views will necessarily prevail.

We have a head start on meeting the challenges of certification by careful articulation of the many changes brought forward in the last decade. These are our land-use planning, the Protected Areas Strategy, the Timber Supply Review, FRBC investments, the Treaty Commission, and our Forest Practices Code - although this proved to be overly prescriptive and hence costly, and I'll discuss that further in a moment.

Professional foresters have had a big role in leading or developing many of these changes, and should be proud of it. But it's not time for us to rest on our laurels yet. Defining, implementing, enforcing, and demonstrating sustainable management of our forests will continue to provide us with a wide range of difficult challenges in many areas and for many years to come. For this morning I'm going to briefly mention a few examples that come to mind.

In land use planning we've accomplished a great deal. We're in sight of completing land use plans and the protected areas strategy for over $70 \%$ of the province. Now we are moving into a new phase, in which the skill and judgement of professionals will be called on to help to set clear objectives for the various zones and areas at the landscape level.

Managing biodiversity at both the stand and landscape levels is a complex challenge. The eyes of the world will be on us continually, judging whether our assessments and treatments are appropriate. Our researchers in this area will be worth their weight in gold.

The forest research agenda will be powerfully affected by market forces and the global acceptability of our practices. If management practices aren't consistent with global standards and expectations, curent issues like the use of clearcutting, the harvesting of our older growth forests, and emerging issues like boreal forest management, will become problematic. We must develop criteria and indicators of sustainability that are meaningful and rigorously science-based, to demonstrate to the world that our forest practices are not only sustainable but amongst the best in the world. Science and technology will be essential to remaining competitive in the global marketplace. And in the end, policy-makers and legislators will still have the difficult task of integrating that science into the management environment, in order to balance social, economic and environmental objectives.

Sustainability has less tangible challenges too. As the extent of original forests on the planet diminishes, their perceived value will increase, and we can expect environmental campaigns to 
continue even if certification is established, which will keep the diplomacy skills of the professional community fully occupied. Population increases will probably bring as many new demands and challenges as emerging scientific information. And no doubt we'll go on being challenged to create higher-value products; to find ways to create employment; to solve the complex issues around stumpage; and we will likely have to contemplate alternative tenure arrangements although we may just still be here talking about that in 50 years!

One complex and lasting series of challenges we will have to deal with, of course, are those facing the province as it moves toward resolution of First Nations' issues following the recent Delgamuukw court decision. I can't possibly address the scale of this issue today... which was addressed by the previous speaker... but we will need to continue to consult carefully with First Nations in our forestry planning and operations while the implications of the decision are clarified.

The overall challenge for foresters will be to do a better job in a complex, rapidly changing policy environment. These few examples of forthcoming challenges in sustainability give just a very short introduction to what will become a crucial chapter in the annals of professional forestry.

I'd like to end this short list with a current example of how challenging this can be - and will become - even when we think we have things in hand. As I mentioned, a few years ago we recognized the need for a consolidated Forest Practices Code and by almost superhuman effort we created one. One giant leap for sustainability - or so we thought. But then we found out the economic and administrative costs of delivering the Code as it was designed, together with higher stumpage rates, were prohibitive. We had set out to regulate our practices and our industry, not to destabilize it or undermine its global competitiveness. Remember, sustainability is a balancing point between social, economic and environmental considerations.

We're reviewing the Code, in order to reduce process while focussing on results, and this brings more reliance on professional accountability. Making any change to the Code, of course, is a sensitive issue, both locally and internationally. We have to ensure the changes we make don't lessen, and are not perceived to lessen, our effectiveness in achieving environmentally sustainable forest management on the ground.

One big factor in the shift toward accountability in the Code leads to my last point. That is the eagerness of most of the professional forestry community to take on this new responsibility and accountability. I sincerely believe this is very praiseworthy and commendable, but we must remember that living up to all the public's expectations for custodianship of their forests is going to be a very tall order.

All our recent work toward sustainable forest management reflects well on our profession. But we must remember that it has all taken place after a period when both the legislators and we as foresters had become significantly out of step with the public's expectations for how their forests would be managed. This led to the need for a very rapid catch-up, in the form of the code and other initiatives. The lesson in this history is that we still have much work to do to cultivate public support as we move forward as a profession to meet our many new challenges. I'm reminded of the old adage "be careful what you wish for, it just might come true".

Accountability this time around has a big price. The whole world is watching and you can bet they're not going to miss a thing. They will have read the Foresters Act. They will know that section 3 says the competence and integrity of individual member foresters are accountable to this association and to the public. And they will know that our association has the power to levy extraordinarily large fines on its members. This is part of being a publicly accountable professional organization. The public may well pursue and test our accountability in this regard.

All of which is perfectly fine if we as individuals, and our association, have matured sufficiently to withstand what is likely to be yet another series of challenges, as has been outlined in this meeting over the past few days. That is, the need for foresters to diligently ensure that policies which confer social and economic advantage today are also scientifically consistent with sustaining the health and productivity of our forest ecosystems for the long term. Because - if it's not you and me as accountable professional foresters - who else could logically bear that responsibility?

In accepting accountability, we must never lose sight of the fact that our first responsibility, and primary concern, must always be to protect the health of our forest ecosystems - and that means the range of forest values, not just timber productivity over the long term. We, at least, are in this for the long haul.

This organization is 50 years old now. That must mean it's nearing some sort of maturity! And that means that collectively we should be well positioned to take up the challenges we've raised this morning - and plenty more, I'm sure, that we haven't even thought of yet!

Our greatest challenge with sustainability is for each of us individually to gain a broad and thorough knowledge, and to apply it with acceptance of the personal responsibility and accountability that that knowledge brings. This is by no means a new idea. Aldo Leopold in 1937 said: "We seem ultimately always thrown back on individual ethics as the basis of conservation policy. It is hard to make a man, by pressure of law or money, do a thing which does not spring naturally from his own personal sense of right and wrong."

If we take anything back from this historic meeting, I hope it will go something like this: Yes, let's practice sustainable forestry because we know if we don't we won't sell our products internationally... and yes, let's not forget about that, when we're being pressured by the details of our daily jobs... and yes, let's do it right so we can help companies to keep making a reasonable rate of return and employees to have satisfying jobs. But most of all, let's each accept our personal accountabilities in practicing sustainable forestry, because we know and understand that, first and foremost, we have a responsibility to the forest itself.

And in fact, this should be easy for us. Over and over I have seen people working together with a care that illustrates how seriously they take this responsibility. It's very tough keeping up with all the changing definitions and expectations of forestry, but as professional foresters we are intelligent... we are dedicated... we have the good fortune of a spectacular forest resource to manage... and I know that we can keep up with changing public interests and social demands.

In conclusion, I'll leave you with two things that can be guaranteed to be sustainable in our forest management. The first is the unending supply of challenges to our professional capabilities. And the second is our individual and collective ability to rise to, and meet, those challenges. 